\title{
FLAVONOIDS FROM ENDOPHYTIC BACTERIA OF COSMOS CAUDATUS KUNTH. LEAF AS ANTICANCER AND ANTIMICROBIAL
}

\author{
FIQIH RAMADHAN, LULUK MUKARRAMAH, FIKRI AINUR RISMA HARDIYANTI OKTAVIA, RIA YULIAN, \\ NURUL HILYATUN ANNISYAH, IIS NUR ASYIAH*
}

Department of Mathematics and Science Education, Study Program of Biology Education Faculty of Teacher Training and Education, University of Jember, Jember 68121, Indonesia. Email: iisnaza.fkip@unej.ac.id

Received: 14 August 2017, Revised and Accepted: 10 October 2017

\section{ABSTRACT}

Objective: The present study aimed to isolate and examine the characteristics of endophytic bacteria from kenikir (Cosmos caudatus Kunth.) leaves, to determine the endophytic bacteria capable of producing flavonoids, and to test their potency as anticancer and antimicrobial.

Methods: The isolation of endophytic bacteria from C. caudatus Kunth. leaf was conducted by technical surface sterilization. Each of these isolates was produced from the insulation and then cultured on a liquid medium of $0.1 \%$ soluble starch, $0.5 \%$ peptone, and $0.15 \%$ yeast extract with a pH of 7 which have been incubated in room temperature for 5 days with agitation of $120 \mathrm{rpm}$ and extracted with ethyl acetate solvent. The extract was then tested for flavonoid content using thin-layer chromatography method. The anticancer ability of flavonoids was tested by brine shrimp lethality test (BSLT) method, while that for antimicrobial, the test used paper disc method.

Results: A total of 15 isolates of endophytic bacteria were successfully isolated from the kenikir leaves, but only 4 isolates produced flavonoids, among others PKM 1 (Serratia sp.), PKM 2 (Neisseria sp.), PKM 17 (Acinetobacter sp.), and PKM 19 (Yersinia sp.). BSLT test results showed that the flavonoids cause mortality in Artemia salina leach with $\mathrm{LC}_{50}$ as much as 16.736 in PKM 17, 17.267 in PKM 2, 18.672 in PKM 1, and 23.411 in PKM 19. The flavonoids also inhibited the growth of pathogens in human-based antimicrobial test results.

Conclusion: Flavonoids produced by four endophytic bacterial isolates from kenikir leaves have great potential as anticancer and antimicrobial.

Keywords: Cosmos caudatus, Leaf, Endophytic bacteria, Flavonoids, Anticancer, Antimicrobial.

(C) 2018 The Authors. Published by Innovare Academic Sciences Pvt Ltd. This is an open access article under the CC BY license (http://creativecommons. org/licenses/by/4. 0/) DOI: http://dx.doi.org/10.22159/ajpcr.2018.v11i1.21987

\section{INTRODUCTION}

Cosmos caudatus Kunth. known as kenikir (Indonesia) or ulam raja (Malaysia) is an edible vegetable. The nutritious kenikir leaves are usually used as an appetite enhancing herb, a bone-strengthening agent, a weak stomach medication, and an insect repellent [1]. Kenikir leaves contain high antioxidant compound equal to $70 \mathrm{mg} / \mathrm{L}$ [2]. Methanol leaf extract of kenikir contains flavonoids and quercetin glycosides potential as cancer drugs [3]. Studies involving kenikir leaves as cancer drugs have been reported to be able to induce apoptosis of colon cancer cells [4], the leukemia cancer cells [5], and breast cancer cells [1].

Aside from being an anticancer, kenikir leaves also proved to be antimicrobial. Extract hexane, diethyl ether, and ethanol leaves of C. caudatus Kunth. were reported to inhibit the growth of Gram-positive bacteria such as Bacillus subtilis and Staphylococcus aureus and Gramnegative bacteria such as Escherichia coli and Pseudomonas aeruginosa in which the minimum inhibitory concentrations (MIC) value ranges for $6.325 \mathrm{mg} / \mathrm{ml}$ [6]. This plant is also reported to possess anti-QS activity against Chromobacterium violaceum with DIZ of $21 \mathrm{~mm}$ and MIC of $31 \mathrm{mg} / \mathrm{ml}$ [7]. Sequential leaf extracts of $C$. caudatus Kunth. screened for antifungal activity using cup method showed that the ethyl acetate extract was the most effective agent in inhibiting fungal growth and spore germination [8].

Kenikir leaves contain phenolic compounds of caffeoylquinic acids, quercetin glycosides, catechins, and proanthocyanidins. Caffeoylquinic acids consist of chlorogenic, neochlorogenic, and cryptochlorogenic [9]. Quercetin glycosides include arabinofuranoside, glucoside, rhamnoside, and rutinososide $[10,11]$. Quercetin is the most dominant flavonoid compound in C. caudatus Kunth. leaf (51\%) [12-14].
Quercetin could act as an antioxidant [15]. Quercetin has extraordinary antioxidant properties caused by its pharmacophores $\mathrm{B}$ ring, and the group $\mathrm{ONOO}^{-}$makes quercetin actable as a strong inhibitor of lipid peroxidation. In addition to the antioxidant properties, quercetin may also increase glutathione concentrations potentially inhibiting free radical formation [16]. Quercetin is able to regulate the cycle of cancer cells by binding to multiple targets, for example, by blocking the cell cycle at the G2/M phase or G1/S transition and also capable of interfering with MMP, thus triggering the release of cytochrome $\mathrm{c}$ in the cytoplasm and the activation of caspase-3 and caspase-7 [17]. Quercetin also inhibits the growth of Staphylococcus aureus, Clostridium botulinum, Actinobacillus actinomycetemcomitans, and Porphyromonas gingivalis [18]

Endophytic microbes are bacterial microorganisms (including actinomycetes) or fungi that spend all or part of their life cycle to live in plant tissues. Endophytic bacteria will not affect or disinfect the host cells $[19,20]$. Each plant tissue possesses endophytic bacteria in it. Endophytic bacteria living in plants can produce secondary metabolite of compounds that resemble or are similar to their hosts and are suspected as a result of coevolution and genetic recombination of the host plants to the microorganism [21]. Therefore, endophytic bacteria in kenikir are expected to produce secondary metabolites similar to kenikir. In addition, the existence of life cycles and the ability of bacteria in multiplying quickly make endophytic bacteria grow and produce secondary metabolites faster as well. In conclusion, endophytic bacteria have the potential to be the vast producer of anticancer and antimicrobial compounds because of its relatively fast growth and large amount. This study aimed to isolate and examine the characteristics of endophytic bacteria from kenikir (C. caudatus Kunth.) leaves, to determine the endophytic bacteria capable of producing flavonoids, as well as to test its potential as anticancer and antimicrobial. 


\section{METHODS}

\section{Isolation of endophytic bacteria}

Isolation of endophytic bacteria from C. caudatus Kunth. leaf was carried out by technical surface sterilization. The obtained leaf samples of $C$. caudatus Kunth. were cleared from the dirt and weighed about $1 \mathrm{~g}$ of its wet weight. The surface of the leaf tissue was sterilized by soaking the leaves in $70 \%$ alcohol for $1 \mathrm{~min}$, and then, NaOCL $3+0.05 \%$ Tween 20 for 3 min. The last step was rinsing in a sterile aquadest for 3 times. Subsequently, the sample was mashed using a sterile mortar until smooth, and its dilution was performed at $10^{-1}$. The suspension at $10^{-1}$ dilution was inoculated on Tryptic Soybean Agar (TSA) medium and incubated for $24 \mathrm{~h}$ at room temperature. As a control, the sterilized kenikir leaves that have not been mashed were streaked on TSA medium [22]. The identification of endophytic bacteria applied the Manual for Identification of Medical Bacteria [23].

\section{Secondary metabolism extraction of endophytic bacteria}

Endophytic bacteria, grown earlier in Erlenmeyer containing sterile liquid medium with composition: $(0.1 \%$ soluble starch, $0.5 \%$ peptone and $0.15 \%$ yeast extract with $\mathrm{pH}$ of 7 ), were incubated in room temperature for 5 days with agitation of $120 \mathrm{rpm}$. This culture was inserted in a sterile tube and then centrifuged at 10,000 rpm for $10 \mathrm{~min}$ to separate the pellets and supernatant. The supernatant was given amyl acetate of 1:1. This mixture was shaken for $15 \mathrm{~min}$ to form three layers. The upper layer was taken and evaporated to obtain the secondary metabolism of endophytic bacteria which was then used for testing its flavonoid content [24].

\section{Thin-layer chromatography (TLC) test}

The supernatant content of the aqueous culture of endophytic bacteria extraction was tested using TLC by heating KLT Silica gel F254 plate in the oven at $110^{\circ} \mathrm{C}$ for $15 \mathrm{~min} .0 .01 \mathrm{~g}$ of secondary metabolism extract and standard quercetin were dissolved in 0.5 acetic acids, and then, bottled in capillary pipe at $1 \mathrm{~cm}$ from the bottom edge of the plate, dried, and eluted with chloroform eluent:methanol (1:4). Observations were made on stain spots on the plate surface under visible light and ultra violet (UV) light at a wavelength of $365 \mathrm{~nm}[25,26]$.

\section{Brine shrimp lethality test (BSLT)}

Anticancer testing used BSLT method involving Artemia salina Leach as test subject. A. salina Leach larvae was hatched by soaking its eggs in seawater for $48 \mathrm{~h}$ in a vessel equipped with an aerator. Parts of seawater that did not contain larvae eggs were illuminated in order the hatched larvae moved toward the light and left its shell [27].

The test execution was carried out by equalizing the final volume of the extract flavonoids with the concentration of the treatment at $0 \mathrm{ppm}, 1$ ppm, $10 \mathrm{ppm}, 100 \mathrm{ppm}$, and $1000 \mathrm{ppm}$ diluted by first adding $5 \mathrm{ml}$ of seawater into each test tube until the flavonoid extract was dissolved, and then, inserted 10 tails of shrimp larvae aged $48 \mathrm{~h}$ in each tube. The test tube was then placed under lighting for $24 \mathrm{~h}$, and the number of dead shrimp larvae was counted. Larvae were considered dead if they did not exhibit any form of movement during several seconds of observation. Each concentration of treatment was replicated 5 times. $\mathrm{LC}_{50}$ values were determined by probit analysis $\mathrm{LC}_{50}[27,28]$.

\section{Antimicrobial test}

The flavonoid extracts resulted by endophytic bacteria isolates were tested on the antimicrobial capabilities on four human pathogenic bacteria (E. coli, Salmonella typhi, Shigella dysenteriae, and Vibrio cholerae) and three human pathogenic fungi (Aspergillus flavus, A. niger, and Candida albicans) by a paper disk method by putting paper discs soaked in the test solution on a solid medium inoculated with bacteria. After the incubation period of $24 \mathrm{~h}$ for bacteria and $72 \mathrm{~h}$ for fungi, the diameter of inhibition zone formed around the paper disc was measured [29]. As control group, chloramphenicol antibiotic was used for bacteria, and ketoconazole antibiotic was used for fungi.

\section{RESULT AND DISCUSSION}

\section{Isolation of endophytic bacteria and TLC test}

15 endophytic bacteria isolates were successfully collected from kenikir (C. caudatus Kunth.) leaves. The bacterial isolates were cultured and then extracted for their flavonoids. All isolates yielded yellow-to-bright yellow extracts. The flavonoids extracts were then tested using TLC. The flavonoid compound tested using TLC with non-reagent-visible-light yielded no color, whereas with reagent-visible-light yielded light yellow color. Using UV light 366 with or without reactants, the compounds showed a blue color $[25,26]$. Based on the observation, 4 positive flavonoid isolates were found as shown in Table 1.

One of the flavonoids in endophytic bacterial isolates of kenikir is predicted to be quercetin compound. The kenikir leaves produced several derived flavonoid compounds such as quercetin 3-0-glucoside, quercetin pentose, quercetin deoxyl-hexose, and catechin, while others are derivatives of phenolic acids [14].

Of the 4 endophytic bacteria, isolates proven to produce flavonoids were characterized using the Manual for the Identification of Medical Bacteria [23]. The identification results of the four bacteria are shown in Tables 2 and 3.

Based on the spread of the characteristics (Tables 2 and 3), PKM 1 refers to Serratia sp., PKM 2 refers to Neisseria sp., PKM 17 refers to Acinetobacter sp., and PKM 19 refers to Yersinia sp. The characteristics of Serratia sp. are motile, rod-shaped, facultative anaerobe, 0.5-0.8 $\mu \mathrm{m}$ in diameter, and $0.9-2 \mu \mathrm{m}$ in length. This species can grow at a temperature of $540^{\circ} \mathrm{C}$ and is naturally found in soil, water, and plant surfaces. Some strains of Serratia. marcescens may produce prodigiosin pigments that are dark red to pink, depending on the age of the bacterial colony. The Neisseria sp. is aerobe, motile, rod-shaped, $0.1-3 \mu \mathrm{m}$ diameter in colony length and yellow in color, Gram-negative, positive in catalase and oxidation, and $\mathrm{H}_{2} \mathrm{~S}$ production. The optimum temperature is $35-37^{\circ} \mathrm{C}$. The Acinetobacter sp. is aerobes, motile, Gram-negative, rod-shaped, $0.1-0.3 \mu \mathrm{m}$ in colony diameter, white and shiny in colony surface, and positive in catalase, oxidase, and $\mathrm{H}_{2} \mathrm{~S}$ production. The optimum growth temperature is $33-35^{\circ} \mathrm{C}$. The Yersinia sp. is stem cellshaped, Gram-negative, aerobe, motile, $0.5-0.8 \mu \mathrm{m}$ in colony diameter, yellow and shiny on the colony surface, positive in oxidase, and negative $\mathrm{H}_{2} \mathrm{~S}$ production. The optimum growth temperature is $28-30^{\circ} \mathrm{C}$.

\section{BSLT}

To find the potential of flavonoids yielded by the four endophytic bacteria, BSLT as the most widely used method to search for new anticancer compounds from plants was used. The BSLT method has been proven to have a correlation with anticancer activity. In addition, it is also easy to do, cheap, fast, and accurate enough [27]. BSLT test results are shown in Table 4.

The result of BSLT test showed that the flavonoids produced by four endophytic bacteria caused the death of $A$. salina leach larvae. The percentage of deaths increased along with the increasing concentrations of flavonoid compounds. The result of probit analysis using SPSS showed that the value of $\mathrm{LC}_{50}$ from PKM 1 flavonoid compound was 18.672 ppm, PKM 2 was 17.267 ppm, PKM 17 was 16.736 ppm, and PKM 19 was 23.411 ppm.

An extract shows toxicity activity if the extract can cause $50 \%$ mortality of the test subjects at concentrations $<1000 \mathrm{ppm}$. Based on these statements, the flavonoid extract from four endophytic bacteria has potential as anticancer, antibacterial, and antifungal due to its toxicity [27].

Flavonoid compounds produced from endophytic bacteria from kenikir leaves are purported to be quercetin. Quercetin is a natural anticancer antioxidant proven both in vitro and in vivo testing. Numerous studies have shown that quercetin significantly inhibits breast, colon, prostate, ovarian, endometrial, and lung cancer. 
Table 1: TLC results of endophytic bacteria

\begin{tabular}{|c|c|c|c|c|c|c|c|}
\hline \multirow[t]{3}{*}{ No } & \multirow[t]{3}{*}{ Bacterial isolate } & \multirow[t]{3}{*}{ Gram (+/-) } & \multicolumn{5}{|l|}{ TLC test results } \\
\hline & & & \multicolumn{2}{|l|}{ Visible light } & \multicolumn{2}{|l|}{ UV $365 \mathrm{~nm}$} & \multirow[t]{2}{*}{ Note } \\
\hline & & & Without reacting & With reacting & Without reacting & With reacting & \\
\hline 1 & PKM 1 & - & - & Bright Yellow & Blue & Blue & Flavonoid \\
\hline 2 & PKM 2 & - & - & Bright Yellow & Blue & Blue & Flavonoid \\
\hline 3 & PKM 5 & - & - & - & Blue & Blue & - \\
\hline 4 & PKM 6 & - & - & - & Blue & Blue & - \\
\hline 6 & PKM 10 & - & - & - & Blue & Blue & - \\
\hline 7 & PKM 11 & - & - & - & Blue & Blue & - \\
\hline 8 & PKM 12 & - & - & - & Blue & Blue & - \\
\hline 9 & PKM 17 & - & - & Bright Yellow & Blue & Blue & Flavonoid \\
\hline 10 & PKM 19 & - & - & Bright Yellow & Blue & Blue & Flavonoid \\
\hline 11 & PKM 20 & - & - & - & Blue & Blue & - \\
\hline 12 & PKM 21 & - & - & - & Blue & Blue & - \\
\hline 13 & PKM 23 & - & - & - & Blue & Blue & - \\
\hline 15 & PKM 26 & - & - & - & Blue & Blue & - \\
\hline
\end{tabular}

TLC: Thin-layer chromatography

Table 2: Morphology observation results of endophytic bacteria producing flavonoids

\begin{tabular}{lllll}
\hline Bacteria isolate & Colony & & & \\
& Color & Form & Elevation & Edge \\
\hline PKM 1 & Red & Circular & Raised & Entire \\
PKM 2 & Yellow & Irreguler & Flat & Lobate \\
PKM 17 & White & Circular & Flat & Entire \\
PKM 19 & Yellow & Circular & Flat & Entire \\
\hline
\end{tabular}

Table 3: Physiological observation results of endophytic bacteria producing flavonoids

\begin{tabular}{llllll}
\hline Bacteria isolate & \multicolumn{2}{l}{ Physsiological observation results } & & Species \\
\cline { 2 - 5 } & Motility & $\mathbf{0}_{2}$ requirement & Catalase & Oxidation & Glucose \\
\hline PKM 1 & + & + & + & + & - \\
PKM 2 & + & + & + & + & - \\
PKM 17 & + & + & + & - & Serratia sp. \\
PKM 19 & + & + & + & + & Acisseria sp. \\
\hline
\end{tabular}

Table 4: BSLT test results

\begin{tabular}{|c|c|c|c|}
\hline Sample & Concentration (ppm) & Mortality (\%) & $\mathrm{LC}_{50}(\mathrm{ppm})$ \\
\hline \multirow[t]{5}{*}{ PKM 1} & 0 & 0 & 18,672 \\
\hline & 1 & 8.42 & \\
\hline & 10 & 40 & \\
\hline & 100 & 79.52 & \\
\hline & 1000 & 97.41 & \\
\hline \multirow[t]{5}{*}{ PKM 2} & 0 & 0 & 17,267 \\
\hline & 1 & 9.57 & \\
\hline & 10 & 41.33 & \\
\hline & 100 & 80.72 & \\
\hline & 1000 & 98.29 & \\
\hline \multirow[t]{5}{*}{ PKM 17} & 0 & 0 & 16.736 \\
\hline & 1 & 9.57 & \\
\hline & 10 & 40 & \\
\hline & 100 & 78.31 & \\
\hline & 1000 & 97.39 & \\
\hline \multirow[t]{5}{*}{ PKM 19} & 0 & 0 & 23.411 \\
\hline & 1 & 9.57 & \\
\hline & 10 & 33.77 & \\
\hline & 100 & 75.31 & \\
\hline & 1000 & 95.49 & \\
\hline
\end{tabular}

BSLT: Brine shrimp lethality test
Some theories underpin the mechanism of flavonoids as anticancer. Flavonoids act as antioxidants through the mechanism of activation of cancer cell apoptosis pathway. The mechanism of cell apoptosis in this theory is due to DNA fragmentation beginning with the release of proximal chains of DNA by reactive oxygen compounds such as hydroxyl radicals. Another effect is flavonoids as inhibitors of cancer proliferation, one of them is by inhibiting the activity of protein kinase that inhibits signal transduction path from the membrane to core cell. Flavonoids inhibit the activity of tyrosine kinase receptors because the increased activity of tyrosine kinase receptors contributes to the growth of malignant cancer cells. Flavonoids also serve to reduce tumor resistance to chemotherapeutic agents [30].

Flavonoids can stimulate apoptosis through several mechanisms such as inhibition of topoisomerase I/II DNA activity, modulation of signaling pathways, decreased expression of Bcl-2 and Bcl-XL genes, enhanced expression of Bax and Bak, and endonuclease activation [4]. Quercetin has the ability to stimulate apoptosis of Caco-2 and HT-29 colon cancer cells and HL-60 leukemia cancer cells by stimulating the release of cytochrome c from mitochondria [5]. Quercetin also showed synergistic effects with cisplatin in vitro and in vivo through inhibition of protein kinase C [31]. 
Table 5: Antimicrobial activity of flavonoids from endophytic bacteria of Cosmos caudatus Kunth. Leaf

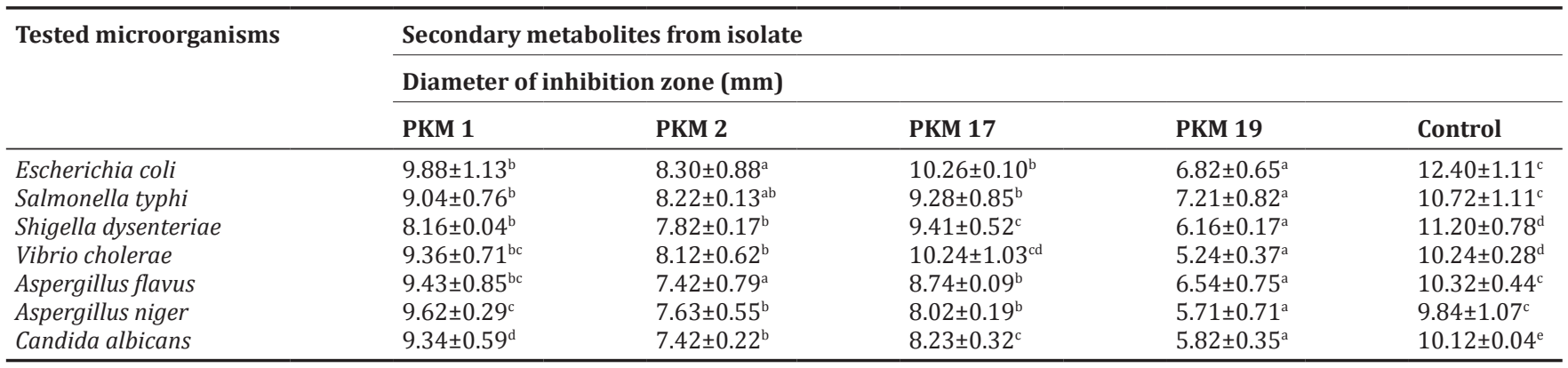

Description: The data are mean of \pm SD, $n=5$. Means with different superscript letters in the same row indicate significant ( $<<0.05$ ) based on LSD test $95 \%$. LSD: Least significant difference

\section{Antimicrobial test}

Besides known as anticancer, kenikir is also antimicrobial. To ascertain whether the flavonoid produced by endophytic bacteria is antimicrobial, the antimicrobial test is done using paper disc method. The results of the measurement of the clear zone diameter can be seen in Table 5.

The results (Table 5) show that flavonoids from endophytic bacteria inhibit human microbial pathogens both bacteria and fungi. The best flavonoids inhibitory against bacteria are produced by PKM 17, while the best inhibitory power against the fungi is the flavonoid produced by PKM 1 .

Flavonoids are bioactive molecules. Its biological activity is closely related to the molecular structure, i.e., their hydroxyl groups or phenolic ring. Phenolic compounds have the capacity to link with proteins and bacterial membrane to form complexes [32]. The flavonoid antibacterial mechanisms include inhibiting nucleic acid synthesis, disrupting cytoplasmic membrane function, and inhibiting energy metabolism [33] and affect peptidoglycan synthesis around a bacterial cell [34].

Quercetin, one type of flavonoids, proved to inhibit Gram-positive and Gram-negative bacteria through the inactivating extracellular proteins $[35,36]$. It has been demonstrated that the antibacterial mechanism of quercetin probably depended on disruption of the membrane and inactivation of extracellular proteins by forming irreversible complexes, but the exact mechanism remains unclear [37].

\section{CONCLUSION}

A total of 15 isolates of endophytic bacteria were successfully isolated from kenikir leaves, but only four produced flavonoids were found to have anticancer and antimicrobial activity.

\section{AUTHORS CONTRIBUTION}

Fiqih Ramadhan, has majorly performed the experiment in the laboratory, and data analysis Luluk Mukarramah, has has majorly performed the experiment in the laboratory Fikri Ainur Risma Hardiyanti Oktavia, has majorly performed the experiment in the laboratory Ria Yulian, has majorly performed the experiment in the laboratory Nurul Hilyatun Annisyah, has majorly performed the experiment in the laboratory Iis Nur Asyiah, has intellectual content, data analyis and responsible for the preparation of article.

\section{CONFLICT OF INTERESTS}

The authors declare that there is no conflict of interest regarding the publication of this article

\section{ACKNOWLEDGMENTS}

The authors would like to thank the Indonesian Ministry of Research, Technology and Higher Education for the financial support through
PKM Research program in 2017, First Vice Rector (Academic and Student Affairs), and Dean of Faculty of Teacher Training and Education of University of Jember

\section{REFERENCES}

1. Pebriana RB, Bantari WK, Esti W, Nur LS, Titi RW, Sugeng R, et al. Apoptotic effect of kenikir leaves (Cosmos caudatus Kunth.) methanolic extract on breast cancer cell line. Pharmacon 2008;9:21-6.

2. Lotulung PD, Kardono LB. Penapisan aktivitas antibakteri, antioksidan dan toksisitas terhadap larva udang Artemia salina ekstrak tumbuhan Asteraceae. Abstrak Pusat Penelitian Kimia LIPI; 2005.

3. Abas F, Shaari K, Lajis NH, Israf DA, Kalsom YU. Antioxidative and radical scavenging properties of the constituents isolated from Cosmos caudatus Kunth. Nat Prod Sci 2003;9:245-8.

4. Ren W, Qiao Z, Wang H, Zhu L, Zhang L. Flavonoids: Promising anticancer agents. Med Res Rev 2003;23:519-34.

5. Amit KT, Roy M, Bhattacharya RK. Natural products as inducers of apoptosis: Implication for cancer therapy and prevention. Curr Sci 2001;80:1391.

6. Rasdi NH, Samah OA, Sule A, Ahmed QU. Antimicrobial studies of Cosmos caudatus Kunth. (Compositae). J Med Plant Res 2010;4:669-73.

7. Tan YP. Antioxidant, Antityrosinase, Antibacterial and Anti-quorum Sensing Activities of Selected Ulam Herbs in Malaysia [MSc thesis]. Malaysia: UCSI University; 2013. p. 141

8. Salehan NM, Meon S, Ismail IS. Antifungal activity of Cosmos caudatus extracts against seven economically important plant pathogens. Int $\mathrm{J}$ Agric Biol 2013;15:864-70.

9. Shui G, Leong LP, Wong SP. Rapid screening and characterisation of antioxidants of Cosmos caudatus using liquid chromatography coupled with mass spectrometry. J Chromatogr B Analyt Technol Biomed Life Sci 2005;827:127-38.

10. Mediani A, Abas F, Khatib A, Tan CP. Cosmos caudatus as a potential source of polyphenolic compounds: Optimisation of oven drying conditions and characterisation of its functional properties. Molecules 2013; 18:10452-64

11. Andarwulan N, Batari R, Sandrasari DA, Bolling B, Wijaya H. Flavonoid content and antioxidant activity of vegetables from Indonesia. Food Chem 2010;121:1231-5.

12. Andarwulan N, Kurniasih D, Apriady RA, Rahmat H, Rotoc AV, Bolling BW. Polyphenols, carotenoids, andascorbic acid in underutilized medicinal vegetables. J Funct Food 2012;4:339-47.

13. Lee TK, Vairappan CS. Antioxidant, antibacterial and cytotoxic activities of essential oils and ethanol extracts of selected South East Asian herbs. J Med Plant Res 2011;5:5284-90.

14. Bunawan H, Baharum SN, Bunawan SN, Amin NM, Noor NM. Cosmos caudatus Kunth: A traditional medicinal herb. Glob J Pharmacol 2014;8:420-6.

15. Sambandam B, Thiyagarajan D, Ayyaswamy A, Raman P. Extraction and isolation of flavonoid quercetin from the leaves of Trigonella Foenum-Graecum and their anti-oxidant activity. Int J Pharm Pharm Sci 2016;8:120-4.

16. Smith AJ, Oertle J, Warren D, Prato D. Quercetin: A Promising flavonoid with a dynamic ability to treat various diseases, infections, and cancers. J Cancer Ther 2016;7:83-95.

17. Gibellini L, Marcello P, Milena NJ, Montagna SD, Erika R, Linda B, et al. Quercetin and cancer chemoprevention. Evid Based Complement 
Alternat Med 2011;2011:1-15.

18. Geoghegan F, Wong RW, Rabie AB. Inhibitory effect of quercetin on periodontal pathogens in vitro. Phytother Res 2010;24:817-20.

19. Misaghi IJ, Donndelinger CR. Endophytic bacteria in symptom free cotton plants. Phytopathology 1990;80:808-11.

20. Sturz AV. The role of endophytic bacteria during seed piece decay and tomato tuberization. Plant Soil 1995;175:257-63.

21. Tan RX, Zou WX. Endophytes: A rich source of functional metabolites. Nat Prod Rep 2001;18:448-59.

22. Hallmann J, Quadt-Hallmann A, Mahaffee WF, Kloepper JW. Bacterial endophytes in agricultural crops. Can J Microbiol 1997;43:895-914.

23. Cowan ST, Steel KJ. Manual for the Identification of Medical Bacteria. London: The Syndics of the Cambridge University Press; 1970.

24. Ahamed MI. Isolation and identification of secondary metabolites producing organisms from marine sponge. Discovery 2012;1:14-7.

25. Marliana SD, Suryanti V, Suyono. The phytochemical screenings and thin layer chromatography analysis of chemical compounds in ethanol extract of labu siam fruit (Sechium edule Jacq. Swartz.). Biofarmasi 2005;3:26-31.

26. Harborne J. Metode fitokimia: Penuntun cara Modern Menganalisis Tumbuhan Cetakan Kedua. Padmawinata K, Soediro I, Penerjemah. Bandung: Penerbit ITB; 1987.

27. Meyer BN, Ferrigni NR, Putnam JE, Jacobsen LB, Nichols DE, McLaughlin JL. Brine shrimp: A convenient general bioassay for active plant constituents. Planta Med 1982;45:31-4

28. Mclaughlin JL, Rogers LL, Anderson JE. The use of biological assays to evaluate botanicals. Drug Info J 1998;32:513-24.

29. Kusmiyati, Agustini NWS. Antibacterial activity assay from Porphyridium cruentum microalgae. Biodiversitas 2007;8:48-53.

30. Woo HD, dan Kim J. Dietary flavonoid intake and risk of stomach and colorectal cancer. World J Gastroenterol 2013;7:1011-9.

31. Middleton EJ, Kandaswami C. The impact of plant flavonoids on mammalian biology: Implications for immunity, inflammation and cancer. In: Harborne JB, editor. The Flavonoids: Advances in Research since 1986. London: Chapman and Hall; 1993.

32. Zongo C, Savadogo A, Somda KM, Koudou J, Traore AS. In vitro evaluation of the antimicrobial and antioxidant properties of extracts from whole plant of Alternanthera pungens H.B.\& K. and leaves of Combretum sericeum G. Don. Int J Phytomed 2011;3:182-91.

33. Cushnie TP, Lamb AJ. Antimicrobial activity of flavonoids. Int J Antimicrob Agents 2005;26:343-56.

34. Rajalakshmi PV, Senthil K. Flavonoid content and antibacterial activity of Albizia julibrissin. Durazz leaf, stem and flower extracts against clinically isolated bacterial pathogens. Int J Pharm Pharm Sci 2014;6:506-8

35. Martini ND, Katerere DR, Eloff JN. Biological activity of five antibacterial flavonoids from Combretum erythrophyllum (Combretaceae). J Ethnopharmacol 2004;93:207-12.

36. Koo H, Jeon JG. Naturally occurring molecules as alternative therapeutic agents against cariogenic biofilms. Adv Dent Res 2009;21:63-8.

37. Cowan MM Plant products as antimicrobial agents. Clin Microbiol Rev 1999; $12: 564-82$ 